\title{
Bolt Device
}

National Cancer Institute

\section{Source}

National Cancer Institute. Bolt Device. NCI Thesaurus. Code C49847.

A screw designed to thread into a nut to form a fastener. 